\section{Shcherbina V., Shvachko D. Borshchik 5.}

\title{
HEAT EXCHANGE SIMULATION IN ENERGY ZONES OF A ROTARYKILN WITH CHANGE OF HEAT RESISTANCE OF THE BODY
}

Об’єктом дослідження є високотемпературні теплові агрегати - обертові печі. Обертові печі використовуються в різних галузях промисловості. Вказане обладнання володіє великими енерговитратами, що обумовлено умовами функціонування пічних агрегатів по дотриманню ряду технологічних вимог до теплового режиму. При цьому проблема високої енергоємності посилюється низьким рівнем корисного використання енергетичних ресурсів. Одними з найбільш проблемних місць є теплотехнічні та експлуатаційні характеристики обертових печей, а також використання футерування зі збільшеним тепловим опором.

В ході дослідження використовувалися фізико-математичні моделі. У роботі запропоновано розраховувати обертову піч для виробництва цементу розміром $5 \times 185$ м та продуктивністю $75 \mathrm{~m} /$ год. Отримано математичну модель для комп'ютерного моделювання технологічних процесів в обертових цементних печах. Розглянуті можливості зменшення витрат палива шляхом підвищення теплового опору футерівки обертової печі. Визначені найбільші енергоємні зони та проаналізовано вплив на теплову ефективність використання додаткової теплоізоляції в різних енергетичних зонах в обертовій печі. Наведені розрахунки та результати числового експерименту. Визначені найбільші рачіональні зони для використання футерівки з додатковою теплоізоляцією. Встановлено, що при комплексному застосуванні пропонованого методу витрати палива в тепловому агрегаті можливо зменшити на 9 \%. А збільшення термоопору футерівки, встановленої в зонах високих температур, дозволить підвищити енергоефективність теплового агрегату. Суттєвою перевагою вказаного методу є той фактор, що збільшення продуктивності печі не вимагає додаткових витрат палива, підвищення температури або збільшення ентальпії продуктів горіння.

В подальшому планується дослідження механізму встановлення теплоізоляційного шару в вогнетриви футерівки, визначення їх оптимальної теплової ефективності та напружено-деформованого стану для виключення можливостей руйнування. А також визначення оптимальної конструктивної форми вогнетриву та комірки з теплоізоляцією.

Ключові слова: обертова піч, тепловий опір футерівки, додаткова теплоізоляція, гази, що відходять, теплова енергія.

Received date: 03.10.2019

Accepted date: 24.10 .2019

Published date: 30.12 .2019
Copyright (C) 2019, Shcherbina V., Shvachko D., Borshchik S. This is an open access article under the CC BY license (http://creativecommons.org/licenses/by/4.0)

\section{Introduction}

A large number of chemical, food, metallurgical, mining, biological and other industries are associated with the processing of finely divided bulk materials. These materials have a number of specific properties - caking ability, low gas permeability, vigilance, and others that impede the flow of chemical reactions and heat and mass transfer processes. Therefore, when choosing equipment for their processing, after analyzing functional, economic, environmental, ergonomic and other criteria, the advantage is most often given to drum-type machines, such as rotary kilns, dryers, granulators, cooling drums, crystallizers. In total, 32 types of stock items are produced in rotary kilns. However, they were most widely used in the building materials industry, where they are the main plants for the production of clinker, expanded clay, lime, perlite and other materials [1-3].

Despite the wide range of use of rotary kilns in various industries, this equipment has significant energy consumption, which is due to the operating conditions of the kiln units in compliance with a number of technological requirements for thermal conditions. At the same time, the problem of high energy intensity is aggravated by the low level of useful energy resources. For example, the thermal efficiency of a large number of rotary kilns for the production of some building materials does not exceed 55-60\% [1-3]. Large productivity, power, dimensions and high temperatures make it difficult to directly study processes in thermal units and related structural elements of machines in real plants. Therefore, model and numerical experimental studies are of particular importance [4-6]. This work is dedicated to solving an important problem focused on the development of mathematical modeling methods in a comprehensive study of energy-intensive high-temperature thermal units, where issues aimed at improving efficiency and reducing energy consumption are of particular relevance.

The energy efficiency of rotary kilns largely depends on the rational use of fuel $[1,7,8]$. Its value is determined mainly by the thermal energy from combustion and the amount that is not used in the working space of the unit. The indicated parameters are characterized by heat capacity, 
temperature of exhaust gases and heat losses through the lining into the environment $[9,10]$.

There are several ways to increase the efficiency of using rotary kilns:

- increasing the completeness of fuel combustion due to more rational modes and choosing the optimal position and direction of the burners [1, 7];

- reduction of heat loss with exhaust gases, due to improved heat transfer between the kiln gases and the processed material through the establishment of various heat exchangers [11];

- reduction of heat through the kiln by increasing the thermal resistance of the lining [12-14].

One of the promising directions on the way to intensifying the operation of the kiln is to reduce heat loss to the environment through the body, by installing additional thermal insulation in the lining and, accordingly, increasing the thermal resistance of the body. So, for example, in cement kilns, these losses reach $20-35 \%$ of the total calorific value of the fuel. It should be borne in mind that the external thermal insulation of the body is not effective, since increasing the temperature of the metal body significantly reduces its bearing capacity.

However, the unresolved question remains how effective the installation of additional thermal insulation along the length of the kiln will be, that is, how effective will be its use in various energy zones. The maximum heat loss in the body is located in the area of high-temperature zones. In these places for cement kilns they reach $40 \%$ of the total consumption through the body. The temperature of the outer surface of the kiln is $300-400{ }^{\circ} \mathrm{C}$, and in some cases reaches even $550{ }^{\circ} \mathrm{C}$. Thus, even insignificant heat losses significantly affect the overall heat consumption. However, the reduction of heat loss through the body is not a guarantee of its effective use for processing material. A fraction of the stored heat enters the gas stream, increasing the temperature of the gas leaving the kiln, thereby increasing energy consumption. Therefore, the object of research is high-temperature thermal units rotary kilns. Thus, the aim of research is a comprehensive study of the impact on the process of additional thermal insulation and determine in which energy zones it will be most effective for improving the thermal and operational characteristics of rotary kilns.

\section{Methods of research}

For research and design work of rotary kilns, the zone calculation method is widely used [1,7]. This method is used to determine a number of characteristic properties of a thermal unit: specific heat consumption, dimensions, amount of raw materials, and others. The kiln is conditionally divided into 8 energy zones, which include:

1 - cooling;

2 - sintering;

3 - exothermic reactions;

4 - decarbonization;

5 - dehydration;

6 - drying;

7 - evaporation;

8 - heating.

However, in the indicated calculation models, the temperature of the exhaust gases and heat loss through the kiln body are entered into the calculation as experimen- tally determined constant parameters. The above does not allow to fully determine the thermal efficiency and take into account the effect. Factors such as a decrease in the thickness of the lining during its wear, which occurs during operation of the thermal unit, also do not allow to establish the effect of additional thermal insulation in individual energy zones. Thus, the zonal calculation method requires additions with dependencies that take into account and determine the indicated values.

Let's consider the heat balance equation for a rotary kiln [2, 7]:

$$
Q=Q_{1}+Q_{2}+Q_{3}\left(t_{w}^{G}\right)+Q_{4}+Q_{5}+Q_{6}\left(t_{w}^{G}\right)+Q_{7},
$$

where $Q$ - the heat input; $Q_{1}$ - the thermal effect of clinker formation; $Q_{2}$ - the water evaporation heat; $Q_{3}-$ losses with exhaust gases; $Q_{4}-$ losses with clinker; $Q_{5}-$ losses with air coming out of the refrigerator; $Q_{6}-$ heat loss with removal; $Q_{7}$ - losses to the environment through the body; $t_{w}^{G}$ - temperature of the exhaust gases from the kiln.

The heat input in (1) is determined by the dependencies:

$$
Q=Q_{n}^{p} \cdot \frac{R_{s}}{P_{p}}+\frac{R_{s}}{P_{p}} \cdot c_{d} t_{d}+\left(G_{c}^{c} c_{c}+G_{W}^{M}\right) t_{M}+\frac{R_{s}}{P_{p}} \cdot V_{W} C_{W} t_{W},
$$

$$
\left\{\begin{array}{l}
F_{n}=\left(\frac{X}{0.124}\right)^{3} \cdot \frac{Q_{n}^{p} \cdot R_{S}}{\sigma \cdot T_{i}^{4}}, \\
Q_{n}^{p} \cdot \frac{R_{s}}{P_{p}}=\frac{\sum_{i-1}^{I}\left(G_{i}^{M}+P_{i}^{M}\right)}{X}, \\
X=\left[0.43 \cdot\left(\frac{F_{n}}{D_{n}}\right)^{0.1}+\sqrt{\left.\frac{Q_{n}^{p} \cdot R_{s}}{\sigma \cdot T_{t}^{4} \cdot F_{n}} \cdot \sqrt{\frac{\sigma \cdot T_{t}^{3}}{\omega_{G}^{0.1}}}\right],}\right. \\
\omega_{G}=\frac{V_{g} \cdot P_{p} \cdot 1000}{3600 \cdot 0.785 \cdot D_{d}^{2} \cdot\left(1-F_{n}\right)} \cdot \frac{T}{273},
\end{array}\right.
$$

where $P_{p}$ - kiln productivity; $Q_{n}^{p}-$ net calorific value of fuel; $c_{d}, t_{d}$ - heat capacity and temperature of dust; $G_{c}^{c}-$ amount of raw material; $c_{c}$ - heat capacity of the raw material; $t_{M}-$ temperature of the raw material enters the kiln; $V_{W}, C_{W}, t_{W}-$ the amount, heat capacity and temperature of the primary and secondary air entering the kiln; $V_{q}$ - working volume of the kiln; $R_{s}$ - fuel consumption; $D_{d}-$ kiln diameter; $T_{i}-$ material temperature at the exit from the $i$-th zone; $T_{t}-$ theoretical temperature of fuel combustion; $T_{G}$ - temperature of the gas stream; $\omega_{Q}$ - rate of combustion products; $F_{n}$ general heat exchange surface; $\sigma$ - emissivity of a black body; $X$ - heat use degree; $G_{i}^{M}$ - practical consumption of heating and conversion in the material relative to the zone; $P_{i}^{M}$ - heat loss to the environment relative to zones and others, which are determined from the material balance or calculation of fuel combustion.

Heat consumption for the formation of clinker $Q_{1}$, for the evaporation of water $Q_{2}$, with clinker $Q_{4}$, and air leaving the refrigerator $Q_{5}$ are determined by known dependences [3, 7].

According to the zonal method of calculation, the enthalpy of the gas stream at the outlet of the rotary heat unit is determined from the relation:

$$
Q_{3}=q_{0}^{G}+\frac{Q_{n}^{p} \cdot R_{s}}{P_{p}}-\sum_{i=1}\left(G_{i}^{M}-P_{i}^{M}\right)
$$


where $q_{0}^{G}$ - amount of heat entering the kiln with fuel, that is, the object $Q_{2}$ depends on the fuel consumption. In addition, the temperature of the exhaust gases from the iln $t_{w}^{G}$ can be determined using the selection method according to the following relationship:

$$
Q_{3}=\left[\begin{array}{l}
\left(V_{\mathrm{H}_{2} \mathrm{O}}^{G} \cdot \frac{R_{s}}{P_{p}}+V_{\mathrm{H}_{2} \mathrm{O}}^{M}\right) \cdot C_{\mathrm{H}_{2} \mathrm{O}}(t)+\left(V_{\mathrm{CO}_{2}}^{G} \cdot \frac{R_{s}}{P_{p}}+V_{\mathrm{CO}_{2}}^{M}\right) \times \\
\times C_{\mathrm{CO}_{2}}(t)+V_{\mathrm{CO}_{2}}^{G} \frac{R_{S}}{P_{P}} \cdot C_{\mathrm{O}_{2}}(t)
\end{array}\right],
$$

where $V^{G}, V^{M}$ - yield of combustion products and raw materials constituting $\mathrm{H}_{2} \mathrm{O}, \mathrm{CO}_{2}, \mathrm{O}_{2}, \mathrm{~N}_{2} ; C$ - the specific heat of $\mathrm{H}_{2} \mathrm{O}, \mathrm{CO}_{2}, \mathrm{O}_{2}, \mathrm{~N}_{2}$.

Heat loss during dust removal is determined by the formula:

$$
Q_{6}=G_{d}^{b} \cdot t_{W}^{G}+\left(G_{M}^{C}-G_{d}^{b}\right) \cdot C_{d} \cdot\left(t_{W}^{G}-t_{d}\right),
$$

example, mullitesilica wool or basalt fiber. It is taken into account that the thermal conductivity of the heat-insulating material is extremely small relative to the refractory material and there is no heat flux through the cell boundary with the heat-insulating material $\partial T / \partial n=0$. The heat flux through the kiln body is determined with the dependence:

$$
\begin{aligned}
& q_{0}=\frac{T_{K 1 i}-T_{K 2 i}}{R_{i}}=\frac{T_{K 1 i}-T_{O C}}{R_{i}+1 / \alpha}, \\
& R_{i}=\frac{H}{\lambda_{i}}\left[\frac{L-\Delta L}{H}-\frac{1}{\beta} \ln \left(1-\frac{\Delta H}{H}\right)\right] ; \beta=\frac{\Delta H}{\Delta L},
\end{aligned}
$$

where $T_{O C}$ - temperature of the environment; $L, H$ - height and length of the refractory; $\lambda_{i}$ - thermal conductivity of the refractory in the corresponding zone; $\Delta L, \Delta H$ - cell size with thermal insulation; $R_{i}$ - integral thermal resistance of the lining.

Lining surface temperature relative to energy zones:

where $G_{M}^{C}$ - heat capacity of $\mathrm{H}_{2} \mathrm{O}, \mathrm{CO}_{2}, \mathrm{O}_{2}, \mathrm{~N}_{2}$.

Heat losses to the environment through the body, based on the heat balance (1), are:

$$
T_{K 2 i}=\frac{\sqrt{R_{i}^{2}\left(A+B \cdot T_{o c}\right)^{2}+2 \cdot R_{i}\left(A+2 \cdot B \cdot T_{K 1 i}-B \cdot T_{o c}\right)+1+B \cdot R_{i} \cdot T_{o c}-A \cdot R_{i}-1}}{2 \cdot B \cdot R_{i}}
$$

$$
Q_{7}=Q-\left[Q_{1}+Q_{2}+Q_{3}\left(t_{W}^{G}\right)+Q_{4}+Q_{5}+Q_{6}\left(t_{W}^{G}\right)\right] .
$$

At the same time, losses to the environment through the body can be determined with respect to losses by energy zones:

$$
\begin{aligned}
& Q_{7}=\sum_{i=1}^{L} P_{i}=\frac{2 \pi r}{P_{p}} \sum_{i=1}^{L} \frac{T_{K 1 i}-T_{K 2 i}}{R_{i}} \cdot L_{i} ; \\
& R_{i}=\frac{\delta_{1 i}}{\lambda_{1 i}}+\frac{\delta_{2 i}}{\lambda_{2 i}\left(T_{K 2 i}\right)}, \\
& \left\{\begin{array}{l}
T_{K 1 i}=T_{K 2 i} \cdot\left[1+R_{i} \cdot\left(3.5+0.062 \cdot T_{K 2 i}\right)\right], \\
T_{K 2 i}=\frac{K_{1} \cdot\left(T_{i}^{G}-T_{K 2 i}\right)+C_{B} \cdot\left[\left(\frac{T_{i}^{G}+273}{100}\right)^{4}-\left(\frac{T_{K 1 i}+273}{100}\right)^{4}\right]}{3.5+0.062 \cdot T_{K 2 i}}, \\
C_{B}=\frac{5.68 \cdot K_{B} \cdot \varepsilon_{m}}{1-\left(1-\varepsilon_{M}\right) \cdot\left(1-F_{\Pi}\right)}, K_{1}=\frac{0.418 \cdot \lambda_{j i}}{D} \cdot\left(\frac{\omega_{G}-D_{n}}{\gamma_{G}}\right)^{0.67}, \\
i=1 \ldots 8
\end{array}\right.
\end{aligned}
$$

where $T_{i}^{G}$ - gas temperatures at the boundaries of the zones; $T_{K 1 i}, T_{K 2 i}$ - temperature of the inner and outer surfaces of the lining by zones; $R_{i}$ - thermal resistance of the kiln body by zones; $\delta_{j i}$ - thickness of the components in the body $(j)$ in relation to the energy zones $(i) ; \lambda_{j i}$ - thermal conductivity of the components in the body $(j)$ in relation to the energy zones (i); $\alpha$ - heat transfer coefficient from the body to the environment for rotary kilns is determined by the dependence:

$$
\alpha=A+B \cdot T_{K 2 i} .
$$

When using iterative calculation methods, instead of the indicated system of equations (9), it is advisable to use the analytical method to determine the temperature of the kiln body, taking into account the introduction of additional thermal insulation into the lining [14, 15]. An effective solution to the problem is the use of a refractory with cells filled with fibrous heat-insulating material, for where $A, B$ - the components of the heat transfer coefficient from the body to the environment.

When determining the temperature of the gas stream at the boundaries of the zones, the well-known equations of the zonal methods are used with respect to the technological method that is being studied [3, 7].

Almost always, when simulating heat transfer in rotary kilns, the temperature field is determined by known heat fluxes. Moreover, the zonal heat balance equations are nonlinear with respect to unknown temperatures.

Thus, in equations (1)-(9) let's obtain a closed system of nonlinear equations in which unknowns are shown in italics. These include: working fuel consumption $R_{s}$, temperature of gases $t_{W}^{G}$, leaving the kiln, temperatures $T_{1} \ldots, T_{j}$, heat loss relative to zones in the environment $P_{i}$, and others. The resulting system of nonlinear equations is solved by the Newton's iterative method. The temperature on the «hot» $\left(T_{K 1 i}\right)$ and «cold» $\left(T_{K 2 i}\right)$ surfaces of the lining is determined from the subsystem of nonlinear equations solved by the tangent method. In this case, the temperature along the boundaries of the zones $T_{i}^{G}$ is determined by the ratios known from the zonal method of calculating. Taking into account the values of thermal resistance $\left(R_{i}\right)$ in different zones of the kiln makes it possible to simulate different amounts of wear of the refractory and the ability to install a heat-insulating layer of the lining.

\section{Research results and discussion}

To test the given mathematical model, a rotary kiln for cement production with a size of $5 \times 185 \mathrm{~m}$ is calculated, with a productivity of $75 \mathrm{t} / \mathrm{h}$. The results of calculating the temperature of the gas stream, the inner surface of the lining and the metal body of the kiln are shown in Fig. 1.

Analyzing the calculation results, it is found that the maximum discrepancy in the data obtained as a result of a numerical experiment and the calculations given in [7] does not exceed $8 \%$ for the temperature of the exhaust gases, and $10 \%$ for fuel consumption. 


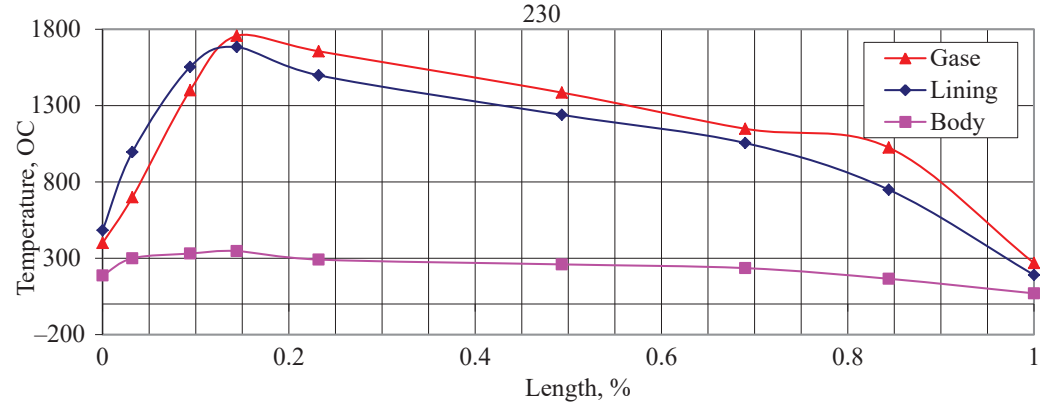

Fig. 1. The calculation of the rotary kiln

Fig. 2 shows the results of calculating the temperature of the exhaust gases from the kiln and fuel consumption when changing the thickness of the lining.

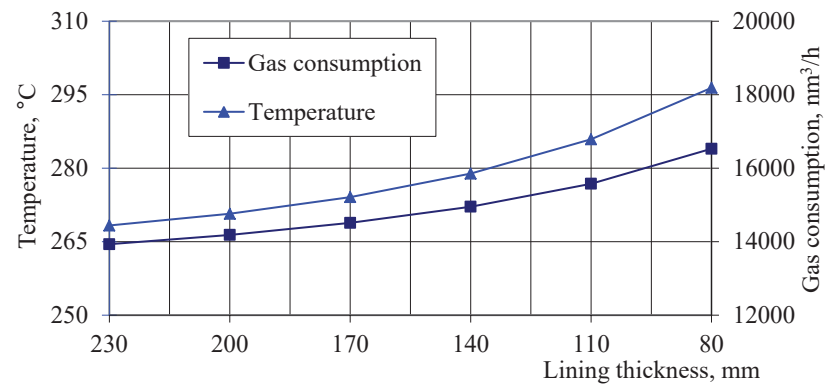

Fig. 2. Gas flow rates and flue gas temperature when changing the lining thickness

Fig. 2 shows the dependence of gas flow on the degree of lining wear. As can be seen from the graphs in Fig. 2, a decrease in the thickness of the lining significantly affects the temperature regime of the kiln unit. So, with a liner thickness of $230 \mathrm{~mm}$, the gas flow rate is $13931.6 \mathrm{~nm}^{3} / \mathrm{h}$, the temperature of the exhaust gas is $268.3{ }^{\circ} \mathrm{C}$. With a decrease in thickness to $80 \mathrm{~mm}$, the flow rate increases and amounts to $16528.6 \mathrm{~nm}^{3} / \mathrm{h}$ at a gas temperature of $296.4{ }^{\circ} \mathrm{C}$. The data obtained from computer simulation are in good agreement with each other and with the results of practical studies of similar thermal units. In the process of wear of the lining, fuel consumption and the temperature of the gas stream leaving the kiln increase. This phenomenon is associated with an increase in heat loss to the environment, which occurs due to losses through the body, as well as with gases that exit the kiln. In this case, heat losses increase in proportion to losses through the body.
To determine the effect of thermal insulation installed in various energy zones on the thermal efficiency of the unit, theobtained data are compared with the results for a kiln with a standard lining and a lining with increased thermal insulation. The specific efficiency of using the heat-insulating layer relative to the energy zone is determined from the dependence:

$$
E^{i}=\frac{R_{s}^{i}-R_{s}}{L^{i}},
$$

where $R_{s}^{i}$ - gas flow rate when installing insulation in the $i$-th zone; $R_{s}$ - gas consumption with a standard design of the kiln lining; $L^{i}$ - length of the plot with thermal insulation.

Additional thermal insulation is modeled by a section whose length corresponds to the length of the energy zone. In this case, fuel consumption is determined at constant, basic kiln productivity. Reducing fuel consumption $E^{i}$, relative to the running length of the lining with additional thermal insulation and taking into account the degree of wear is shown in Fig. 3. The relative length of the kiln is indicated along the abscissa (scale not taken into account).

The calculation is performed for the lining thickness of $230 \mathrm{~mm}, 200 \mathrm{~mm}, 170 \mathrm{~mm}, 140 \mathrm{~mm}, 110 \mathrm{~mm}, 80 \mathrm{~mm}$. As can be seen from the graph in Fig. 3, the greatest effect is achieved by the installation of additional thermal insulation in high-temperature zones. The maximum reduction in fuel consumption occurs in the zones of decarbonization and exothermic reactions. Thus, when installing insulation in the decarbonization zone, fuel economy is $7.85 \mathrm{~nm}^{3} / \mathrm{m}$ per linear meter of the enclosed lining, and at $80 \mathrm{~mm}$ it increases to $16.8 \mathrm{~nm}^{3} / \mathrm{m}$. This is primarily due to a decrease in heat loss to the environment due to thermal insulation casing and reduction in heat loss with exhaust gases. It is worth noting that with a decrease in heat loss, an increase in the performance of a rotary unit is possible.

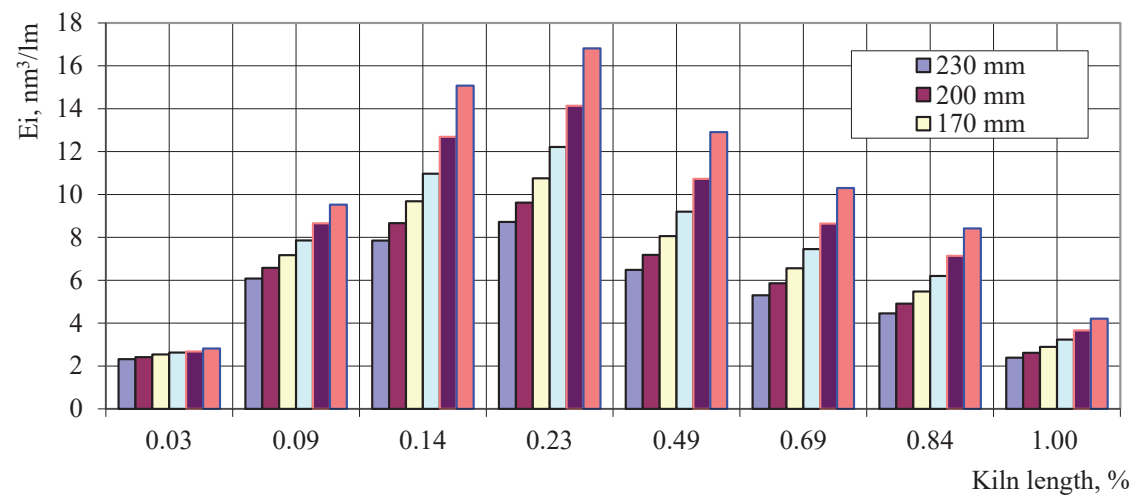

Fig. 3. Fuel consumption reduction when using additional thermal insulation 
Fig. 4 shows the change in fuel consumption with additional thermal insulation depending on the degree of lining wear in various energy zones.

From the obtained graphs in Fig. 4 it can be seen that the efficiency of additional thermal insulation increases with decreasing lining thickness. When installed in low temperature zones, the efficiency of its use is reduced. For example, in the eighth zone, the maximum fuel economy is $2.4 \mathrm{~nm}^{3}$ with a thickness of $230 \mathrm{~mm}$ and $4.2 \mathrm{~nm}^{3}$ with large wear of the lining up to $80 \mathrm{~mm}$. Low energy efficiency of low-temperature zones is explained by low working capacity, fuel exergy in these zones. The latter is explained by the maintenance of a normal thermal regime in the high-temperature zone; it requires an increase in fuel consumption with a decrease in the thermal resistance of the lining. Due to this, at the exit from the zone, the enthalpy of the gas stream increases, however, the additionally received heat is not used effectively in the preparatory zones.

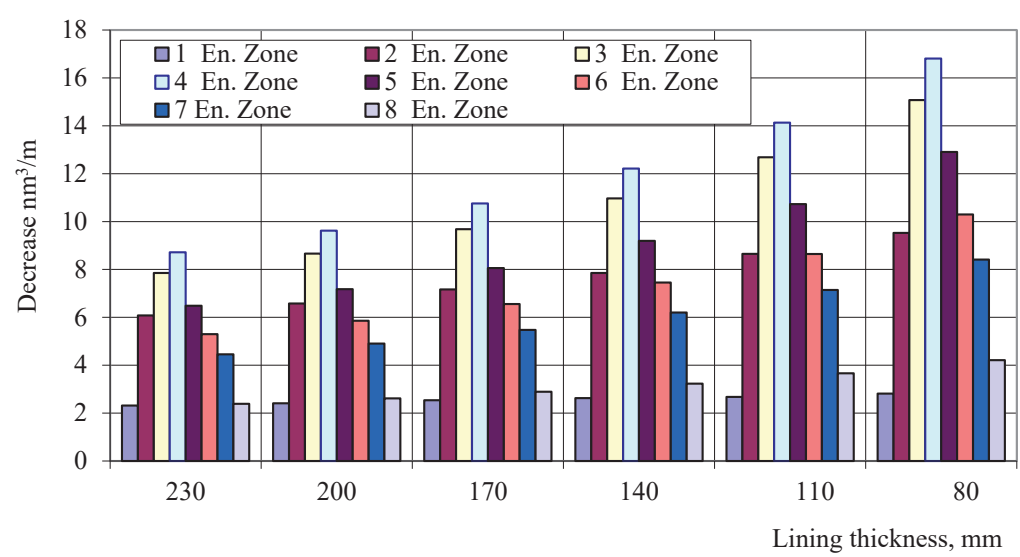

Fig. 4. Change in fuel consumption from lining wear

The temperature of the gas stream in the simulation of fuel consumption and constant performance does not significantly affect the temperature of the exhaust gases from the kiln. Comparing the data for gases only, the exhaust and obtained when calculating the heat balance for the 4th energy zone, it is possible to note that with lining of $230 \mathrm{~mm}$ the temperature of the gases decreases slightly, and varies from $268.3^{\circ} \mathrm{C}$ to $266.3^{\circ} \mathrm{C}$. Moreover, the decrease in heat loss is $1503.8 \mathrm{MJ} / \mathrm{h}$. For a lining with a thickness of $80 \mathrm{~mm}$, the temperature of the gases varies from $296.4{ }^{\circ} \mathrm{C}$ to $293.1{ }^{\circ} \mathrm{C}$, which gives a heat saving of $2941.9 \mathrm{MJ} / \mathrm{h}$. Significant savings in thermal energy with exhaust gases are associated with a slight decrease in the amount of gas. But mainly, with a decrease in the amount of primary and secondary air, the amount of which in this case is $11.02 \mathrm{~nm}^{3} / \mathrm{m}^{3}$ of gas.

It should be noted that for rotary kilns operating according to the «dry» method, that is, they have energy zones in the kiln unit 1-4, the use of thermal insulation will be effective for complete thermal insulation of the entire kiln, with the exception of the cooling zone.

\section{Conclusions}

In the course of the work, a more detailed mathematical model is developed and implemented to study energyintensive high-temperature thermal units with a numerical determination of such factors as the temperature of the exhaust gases and the change in the thickness and thermal resistance of the lining. This allowsto determine the effect of additional thermal insulation on the performance of a rotary kiln. The specified model allows for more complete calculations and determines the thermal efficiency of the kiln in a complex setting.

When studying the efficiency of using a kiln with additional thermal insulation, it is found that its use in high-temperature zones makes it possible to reduce fuel consumption by $3-4 \%$. It is also possible to increase the productivity of the kiln. With the full use of these approaches, the overall energy efficiency of a thermal unit can be increased by $9 \%$. Due to the reduction in fuel consumption, losses to the environment through the body and with the gases escaping are reduced, that is, its utilization rate increases. Thus, the analysis makes it possible to determine the effect of additional thermal insulation installed in various energy zones on the thermal efficiency of a rotary kiln. As a result, it can be concluded that an increase in the thermal resistance of the lining installed in high temperature zones makes it possible to increase the energy efficiency of the thermal unit. A significant advantage of this method is the fact that an increase in kiln productivity does not require additional fuel consumption, an increase in temperature, or an increase in the enthalpy of combustion products.

In the future, it is planned to study the mechanism for establishing a heat-insulating layer in the refractories of the lining, determining their optimal thermal efficiency and stress-strain state to eliminate the possibility of destruction. As well as determining the optimal structural form of the refractory and the cell with thermal insulation.

\section{References}

1. Lisienko, V. G., Schelokov, Ia. M., Ladygichev, M. G., Lisienko, V. G. (Ed.) (2004). Vraschaiuschiesia pechi: teplotekhnika, upravlenie i ekologiia. Kn. 1. Moscow: Teplotekhnik, 688.

2. Taimasov, B. T. (2003). Tekhnologiia proizvodstva portlandcementa. Shymkent: Izd-vo IUKGU, 297.

3. Shcherbina, V. Yu. (2017). Rozoytok teorii ta udoskonalennia tekhnolohichnykh protsesiv pry vyrobnytstvi budivelnykh materialiv u vysokotemperaturnykh ahrehatakh. Kyiv: KPI im. Ihoria Sikorskoho, 398.

4. Watkinson, A. P., Brimacombe, J. K. (1978). Heat transfer in a direct-fired rotary kiln: II. Heat flow results and their interpretation. Metallurgical Transactions B, 9 (3), 209-219. doi: http://doi.org/10.1007/bf02653686

5. Hanein, T., Glasser, F. P., Bannerman, M. N. (2017). One-dimensional steady-state thermal model for rotary kilns used in the manufacture of cement. Advances in Applied Ceramics, 116 (4), 207-215. doi: http://doi.org/10.1080/17436753.2017.1303261

6. Barr, P. V., Brimacombe, J. K., Watkinson, A. P. (1989). A heattransfer model for the rotary kiln: Part II. Development of the cross-section model. Metallurgical and Materials Transactions B, 20 (3), 403-419. doi: http://doi.org/10.1007/bf02696992

7. Khodorov, E. I. (1968). Pechi cementnoi promyshlennosti. Leningrad: Stroiizdat, 456

8. Ngadi, Z., Lahlaouti, M. L. (2017). Impact of Using Alternative Fuels on Cement Rotary Kilns: Experimental Study and Modeling. Procedia Engineering, 181, 777-784. doi: http://doi.org/ 10.1016/j.proeng.2017.02.465 
9. Tada, É. F. R., Bück, A., Casciatori, F. P., Tsotsas, E., Thoméo, J. C. (2017). Investigation of heat transfer in partially filled horizontal drums. Chemical Engineering Journal, 316, 988-1003. doi: http://doi.org/10.1016/j.cej.2017.01.120

10. Herz, F., Mitov, I., Specht, E., Stanev, R. (2012). Experimental study of the contact heat transfer coefficient between the covered wall and solid bed in rotary drums. Chemical Engineering Science, 82, 312-318. doi: http://doi.org/10.1016/ j.ces.2012.07.042

11. Shcherbina, V. Yu., Sakharov, O. S., Samylenko, Yu. V., Bobakh, V. V. (2009). Doslidzhennia termomekhanichnykh navantazhen v obertovii pechi z vykhrovym teploobminnykom. Naukovi visti $N T U U \ll K P I », 6,26-33$.

12. Sakharov, O. S., Scherbina, V. Iu., Chzhan Iulin, Bobakh, V. V. (2009). Modelirovanie vliianiia formy ogneupora na teplovuiu effektivnost futerovki vraschaiuscheisia pechi. Eastern-European Journal of Enterprise Technologies, 4 (10 (40)), 58-65. Available at: http://journals.uran.ua/eejet/article/view/22438

13. Sharikov, Iu. V., Markus, A. A. (2013). Matematicheskoe modelirovanie teplovykh polei vo fragmente futerovki vraschaiuscheisia pechi. Metallurg, 12, 23-26.

14. Kesselheim, B., Kassau, K., Feliciano, C., Jansen, H., Hackenberger, L., Schemmel, T. (2014). Development of a double layer lining for dri production in rotary kilns: energy savings and wear resistance. 19th IAS Steel Conference Ironmaking, Steelmaking, Rolling and Steel Products, At Rosari. Argentina. Available at: https://www.researchgate.net/publication/267267672

15. Shvachko, D. G., Scherbina, V. Iu. (2019). Methods of operational calculation of thermal conditions in packaged refractories. Proceedings of the NTUU «Igor Sikorsky KPI». Series: Chemical Engineering, Ecology and Resource Saving, 1 (18), 102-109 doi: http://doi.org/10.20535/2617-9741.1.2019.171193

Shcherbina Valeriy, Doctor of Technical Sciences, Professor, De partment of Chemical Polymer and Silicate Engineering, National Technical University of Ukraine «Igor Sikorsky Kyiv Polytechnic Institute», Ukraine, e-mail: xpsm@ukr.net, ORCID: http://orcid.org/ 0000-0002-7218-3868

Shvachko Denis, Assistant, Department of Chemical Polymer and Silicate Engineering, National Technical University of Ukraine «Igor Sikorsky Kyiv Polytechnic Institute»,Ukraine, e-mail: Max_shmag@ukr.net, ORCID: http://orcid.org/0000-0001-6031-1490

Borshchik Serhiy, Senior Lecturer, Department of Chemical Polymer and Silicate Engineering, National Technical University of Ukraine «Igor Sikorsky Kyiv Polytechnic Institute»,Ukraine,e-mail:sa_borshik@ukr.net, ORCID: http://orcid.org/0000-0003-0293-8169 